Thomas Schlüter

Geological Atlas of Africa 


\section{Geological Atlas of Africa}

With Notes on Stratigraphy, Tectonics, Economic Geology, Geohazards and Geosites of Each Country

With contributions by Martin H. Trauth

With 249 Figures and a CD-ROM

黛 Springer 


\section{Author}

Prof. Dr. Thomas Schlüter

UNESCO Nairobi Office

P.O. Box 30592

Nairobi

Kenya

ISBN 10 3-540-29144-x Springer Berlin Heidelberg New York

ISBN 13 978-3-540-29144-2 Springer Berlin Heidelberg New York

Library of Congress Control Number: 2005933041

This work is subject to copyright. All rights are reserved, whether the whole or part of the material is concerned, specifically the rights of translation, reprinting, reuse of illustrations, recitation, broadcasting, reproduction on microfilm or in any other way, and storage in data banks. Duplication of this publication or parts thereof is permitted only under the provisions of the German Copyright Law of September 9, 1965, in its current version, and permission for use must always be obtained from Springer-Verlag. Violations are liable to prosecution under the German Copyright Law.

Springer is a part of Springer Science+Business Media

springeronline.com

○) Springer-Verlag Berlin Heidelberg 2006

Printed in Germany

The use of general descriptive names, registered names, trademarks, etc. in this publication does not imply, even in the absence of a specific statement, that such names are exempt from the relevant protective laws and regulations and therefore free for general use.

Cover design: E. Kirchner, Heidelberg

Production: A. Oelschläger

Typesetting: Camera-ready by E. Sillmann

Printed on acid-free paper 30/2132/AO 543210 


\section{Acknowledgements}

Over the last 8 years since the inception of the Geological Atlas of Africa Project, I have been fortunate to have had support from many individuals and institutions in several African, European and North American countries. My interest in the compilation of geological overview maps of Africa grew out from the conviction of my late supervisor, Walter G. Kühne, who had taught me that basic understanding of the geology of an area or region will never happen without initial observation of the respective available geological map. It is therefore my hope that by critical evaluation of the here presented maps further scientific work may be successfully carried out.

I am indebted to a great number of individuals for assistance in many areas beyond my own discipline of Historical Geology and Palaeontology. Financial support was received from DAAD (German Academic Exchange Service), namely Mr. Cay Etzold, Director of the DAAD Office in Nairobi from 2001-2005. My colleagues in the UNESCO Nairobi Office, Dr. Paul Vitta, Prof. Joseph Massaquoi, Alice Ochanda and Dr. Robert Höft (now Toronto) provided an environment that was very innovative for the creation of the maps and the text of the atlas.

Similarly I was encouraged by my colleagues at UNESCO Headquarters in Paris, Drs. Wolfgang Eder, Robert Missotten and Margarete Patzak. Profs. Britta Schütt (Berlin), Jürgen Wohlenberg (Hannover), Volker Jacobshagen (Berlin), Eckard Weilbrecher (Graz), Peter van Straaten (Guelph), Theo Davies (Eldoret), Sospeter Muhongo (Dar es Salaam), Henry Kampunzu+ (Gaborone), Manuel Pinto (Porto) and Dieter Jäkel (Berlin) contributed in many ways significantly to the final text and sometimes with photographs of various geosites. Dr. Andreas Bergner (Potsdam), Wolfgang Zils (Berlin) and Dr. Christa Werner (Berlin) provided an invaluable mass of information on the geology of East Africa. To Dr. Wolfgang Wramik (Rostock) I am indebted for his contribution on the island of Socotra.
Digitizing of various printed maps was done by Dirk Spengler (Utrecht), Nadja Insel (Potsdam) and Stephen Mogere (Nairobi). The final layout of the maps and the complete page design was created by Dipl.-Ing. Elisabeth Sillmann (Landau/Pfalz).

I am grateful to Dr. Christian Witschel (Heidelberg) for the incorporation of this atlas into the Springer Geosciences Programme.

I acknowledge the following copyright holders for permission to use copyright material:

BBC Books, photographs on ps $38 ; 224$.

Borntraeger Verlag, photographs 18; 20; 91

DuMont Buchverlag, photographs 28; 29.

Ferdinand Enke Verlag, photographs $2 ; 4$.

Geological Society of South Africa, photographs on ps $62 ; 193 ; 217$.

Harry N. Abrams, photographs $87 ; 212,262$

National Geographic, photographs on ps $17 ; 33$.

Der Spiegel, photograph on pg 95 left.

Struik, photographs on ps $10 ; 12$.

Time, frontispiece July 2002

Weidenfeld \& Nicholson, photographs on ps $49 ; 71 ; 77 ; 139$.

World Wild Fund for Nature, photographs on ps $24 ; 27 ; 46$

Every effort was made to trace the copyright holders, but if any of them inadvertently has been overlooked, the necessary arrangements will be made at the first opportunity. 


\section{Preface}

This atlas is intended primarily for anybody who is interested in basic geology of Africa. Its originality lies in the fact that the regional geology of each African nation or territory is reviewed country-wise by maps and text, a view normally not presented in textbooks of regional geology. It is my belief, that there has long been a need in universities and geological surveys, both in Africa and in the developed world, for summarizing geological maps and an accompanying basic text utilising the enormous fund of knowledge that has been accumulated since the beginning of geological research in Africa in the mid $-19^{\text {th }}$ century. I hope that, in part, the present atlas may satisfy this need.

The idea to compile the atlas resulted from my teaching experience at African universities for more than 20 years, and after I had witnessed that my colleagues there often had no access to geological overview maps, references and literature of other African countries, sometimes badly needed for teaching purposes. In western eyes Africa is often perceived only as a land of adventurers and explorers, but while Africa is undeniably diverse and different, it has never been a lost continent - only unfamiliar, underappreciated, misunderstood or forgotten. Anybody who has ever gone to Africa has taken a part of it away and left something behind. The results have not been always good, nor have they always been bad, but they have all gone into the mix that makes up the African society. The atlas is therefore intended to build capabilities and capacities at various places in Africa, so that the people there can later continue on their own with what I had begun.

The atlas is subdivided into four chapters centering on regional geological aspects of each African country or territory. The first chapter defines the scientific issues involved in the preparation of the atlas and provides some background for the arrangement of how the atlas was done. The second chapter is devoted to the history of geological mapping in Africa, necessary for a fuller appreciation of why this work in Africa is worth doing. Chapter 3 provides an executive summary on the stratigraphy and tectonics of Africa as a whole, i. e. in the context of no political boundaries. The main part of the atlas lies in Chapter 4 , where in alphabetical order each African country or territory is presented by a digitized geological overview map and an accompanying text on its respective stratigraphy, tectonics, economic geology, geohazards and geosites. A short list of relevant references is also added. The atlas, essentially devoted to African geology, offers in a condensed way data on all aspects of current geoscientific issues that may in future contribute to the development of this continent. 


\section{Contents}

Chapter 1

Aims and Concepts of the Atlas

Chapter 2

Early Geological Maps of Africa

Chapter 3

Tectonostratigraphic Synopsis

Chapter 4

Review of Countries and Territories

Algeria

Madagascar

142

Angola

Madeira (Portugal)

146

Benin

42

Malawi

148

Botswana

46

Mali

152

Burkina Faso

50

Mauritania

156

Burundi

Mauritius

160

Cameroon

56

Morocco

162

Canary Islands (Spain)

60

Mozambique

168

Cape Verde

Namibia

172

Central African Republic

66

Niger

176

Chad

68

The Comoros

(Mayotte still under French administration)

Democratic Republic of Congo (DRC)

Nigeria

180

Reunion (France) 186

Republic of Congo

Rwanda

188

São Thomé \& Príncipe

Djibouti

Senegal

194

84

Seychelles

198

Egypt

Sierra Leone

202

Equatorial Guinea

Socotra (Yemen)

206

Eritrea

92

Somalia

208

Ethiopia

South Africa

212

Gabon

98

Sudan

218

The Gambia

104

Swaziland

222

Ghana

108

Tanzania

Guinea

110

232

Guinea-Bissau

114

Togo

Ivory Coast / Cote d'Ivoire

118

Tunisia

Kenya

120

Uganda

Lesotho

Western Sahara (under Moroccan administration)

Liberia

130

134

Zambia

Libya

138

Zimbabwe 


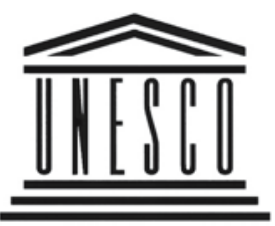

P. B. VITTA, Nairobi, Kenya

F. W. EDER, Paris, France

(Directors)

\section{DAAD}

C. ETZOLD, Nairobi, Kenya (Director)

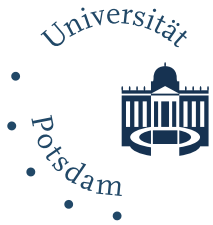

M. H. TRAUTH,

Potsdam, Germany

(Privatdozent)

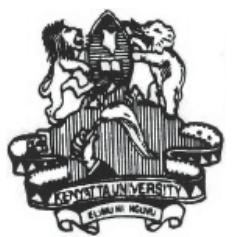

S. N. MOGERE, Nairobi, Kenya

(Research Fellow)

E. SILLMANN, 